The Review of Finance and Banking

print ISSN 2067-2713, online ISSN 2067-3825

Volume 12, Issue 1, Year 2020

http://dx.doi.org/10.24818/rfb.20.12.01.01, Pages 7-18

\title{
IMPEDIMENTS IN USE OF FINANCIAL SERVICES: EVIDENCE FROM NORTH EAST INDIA
}

\author{
SANKHARAJ ROY
}

\begin{abstract}
The present study assesses the factors that are significantly related to the use of financial services among the people living in the North-Eastern States of India. This part of the geographical area has a low penetration of banking and financial services as reported in various documents by the regulators. The use of financial services gives a precise picture of the inclusiveness of the financial system. Financial inclusion does not merely mean having a bank account but using that bank account to derive benefits from various financial services. The present study will try to find out the factors acting as impediments towards the use of financial services and affecting the choice of using or not using any such financial services and products. The study is based on the primary data collected using a questionnaire from 1,948 respondents spreading across three states of North East India. Tobit regression analysis is used as the censored regression model to find out the linear relationship between variables affecting the use of financial services. Fitting Tobit regression model, it is found that, the critical factors that are significant towards the use of financial services are financial awareness, economic status of the members, the suitability of financial products, income, education, age of the user and presence of banking correspondents.
\end{abstract}

\section{Introduction}

Financial inclusion is a multidimensional approach encompassing various dimensions. There exists no single definition or dimension to define financial inclusion. In general, financial inclusion means timely delivery of financial products and services at an affordable cost to the low-income section of the people who are lying at the bottom of the pyramid. Financial inclusion is the process of ensuring access to appropriate financial products and services needed by all sections of the society in general and vulnerable groups such as weaker sections and low-income groups in particular at an affordable cost fairly and transparently by mainstream institutional players (Nair \& Tankha, 2015). Financial inclusion is also defined as the process through which the access to financial services can be increased, and the use of these financial services is maximized while reducing the inadvertent barriers perceived by those individuals who don't get associated with the formal financial system (Camara, Pena, \& Tuesta, 2014).

Continued financial exclusion has become a significant concern for policymakers across the globe. In India, despite the low level of formal bank account, which is only $35 \%$ as per the census of 2011, the household is the most significant contributor to national savings (Kant, 2014). The families not having access to mainstream credit and insurance can benefit through the use of formal savings as it enables the building of safety nets to smooth shocks (Karlan \& Morduch, 2009). The vital indicator to measure financial inclusion is the use of financial

Received by the editors June 19, 2019. Accepted by the editors April 25, 2020.

Keywords: Finance, Financial Inclusion, Financial Services, Formal Credit, Banking Services, North East India.

JEL Classification: G2,G21,G28,I3.

Sankharaj Roy, PhD, State Mission Manager (Finance),Rural Skills Division, Tripura Rural Livelihood Mission (TRLM), Tripura, India. E-mail: sankharajroy@gmail.com.

This paper is in final form and no version of it will be submitted for publication elsewhere. 
services (savings, insurance, payment, remittances, overdraft facility, etc.) by the impoverished and vulnerable groups of people.

Financial exclusion concern is a deep-rooted and complex problem affecting a large section of the world population. Regulatory authorities with the support of the State, Banks, NGOs, SHGs and Micro-Finance Organizations are working together to devise plans for the financial inclusion of the underprivileged people. To augment the process of financial inclusion, the Self Help Group (SHG)-Bank Linkage Program was started for delivering financial services to the poor to uplift their economic condition and decrease their dependency on informal credit (Abid, 1993). For this, these organizations have to identify the factors that affect the financial inclusion of members of the SHGs. The use of mainstream financial products such as savings, credit, insurance, remittances, online banking, etc. helps to raise the propensity of consumption and mitigate risk caused by unforeseen needs or by the asymmetrical flow of income (Allen, Demirguc-Kunt, Klapper, \& Peria, 2012). The present study explores to identify the factors that affect the financial inclusiveness of the people living in three states of North East India in the formal banking sector. Besides, having access to financial services but not using those, amounts to voluntary exclusion. Voluntary exclusion poses a significant threat to financial inclusiveness because of the dearth of awareness and willingness that restrict the use of basic financial services despite having access to them (Sinha, Pandey, \& Madan, 2018). The study has considered voluntary exclusion while framing the model. The present study will make an attempt to determine the factors affecting voluntary as well as involuntary financial exclusion looking attentively from the demand side in order to facilitate understanding of the barriers that may be preventing people particularly residing in the North-Eastern states of India from use of basic financial services. Financial services do not necessarily mean credit facility but a host of other services which one needs for a better life, like sufficient savings, easy payment services, affordable insurance, availing govt. facilities, etc. The indicators considered here are the demographic factors along with financial awareness, connectivity to financial institutions, the suitability of the product, and the presence of business correspondents in those areas. The analysis found that among the factors mentioned above some factors like gender, age, education level, income, suitable banking products, financial awareness and presence of banking correspondents seem to be statistically significant and having a direct or indirect impact on one's decision to use a financial product or service. Building a financial system for people who have easy access to various financial services is a key concern for policymakers. Yet the usage aspect of the financial system has often been ignored because of unavailability of data from user's perspective as who has been using which financial services, simultaneously there is also a shortage of systematic information regarding barriers which can be any of the factors like demographic and socio-economic attributes, suitable product type, connectivity to financial institutions, financial awareness, etc. that confines one's usage of financial services. The present study tries to uncover the causes that avert one's decision to use a particular financial service from a banking system. So, the main objective of this study is to ascertain the determinants affecting the use of formal financial services from selected states situated in North East India.

The rest of the paper is structured as follows. In Section 2 the paper tries to develop a conceptual framework by studying various existing works of literature related to the subject. Section 3 exemplifies the model used in the study, descriptions of the factors and sampling design. The next section that is section 4 epitomizes the working of the statistical model to analyze the primary data collected to find out significant factors determining the use of various financial services and products. It also discusses the findings derived from the analysis. In the

last section, the paper ends with a conclusive statement emphasizing the fact that the use of formal financial services among the people should augment.

\section{Review of Literature}

A report of the National Sample Survey Organization (NSSO) stated that 76 percent of the rural household is indebted to moneylenders to meet their basic credit requirements. Such a 
huge number of people still dependent on the informal source of finance because of their inability to access and use credit facilities from formal institutions. This is true for other financial services also like savings, insurance, remittances, etc. Exclusion can generally happen in the presence of price and nonprice barriers when people don't use or make very little use of financial services (Ford \& Rowlingson, 1966; Kempson \& Whyley, 1998). Also, financial exclusion is perceived as the lack of ability to access essential financial services due to barriers linked with access, conditions, prices, marketing or self-exclusion (Akpandjar, Quartey, \& Abor, 2013). The use of mainstream financial products such as savings, credit, insurance, remittances, online banking, etc. helps to raise the possibility of consumptions and mitigate risk caused by unforeseen needs (Allen, Demirguc-Kunt, Klapper, \& Peria, 2012). The socio-economic conditions of the people in the rural areas are a bottleneck in motivating a person to use formal financial products (Demirgüc-Kunt \& Klapper, 2013).

Information and Communication Technology (ICT) can play an essential role in bringing banking to the door of the customer at a less operating cost (Gupta, 2011). Brynjolfsson \& Hitt (2000), Das (2010) and Gangopadhyay (2009) have also stressed on the benefits of using Information and Communication Technology that can cut down the cost of coordination, information processing, and transactions.

Financial needs are more prone to be financially included in the formal banking system than having the capacity to save (Beck, Demirgüç-Kunt, \& Martines Peria, 2008). Ownership of land or house property increases the possibility of using banking services (Collins \& Daryl, 2009). Bhattacharya (2016) analyzed the characteristics and determinants of financial inclusion using socio-economic variables such as gender, age, income, savings, and investments along with other demographic variables. Sahoo, Pradhan, \& Sahu (2017) have revealed in their study that education, household size, ownership of land as collateral, annual income, as significant determinants of financial inclusion.

Some farmers in rural areas are using mobile devices to do bookkeeping, making payment as well as receiving money (Rogers, 2003). Nwuke (1997) found that there is a positive effect of bank density and urbanization on the mobilization of savings. The use of ICT devices reduces transaction costs, thus expected to increase savings. Information technology has the power to bring down the cost of the transaction, which will aid in spreading financial inclusion as evident from Africa and Latin American countries (Hishigsuren, 2006).

Fernandes, Lynch Jr., \& Netemeyer (2014) found that financial education explained only a minimal percentage of changes in the studied financial behavior. The advantages of this financial illiteracy are taken by the informal agencies that charge exorbitant interest rates (Clarke, George, L., \& Zou, 2006). Those people who are financially literate are in a better position to manage their budgeting and finance and making financial decisions (Moore, 2003; Perry \& Morris, 2005; Campbell, 2006; Lusardi \& Olivia, 2011).

Physical infrastructure comprising road conditions to bank branches, the distance of bank branches /ATMs or post offices, Linking market to SHG products, and accessing information about various financial products and services play a significant role in enabling an individual to access multiple banking and financial products. The importance of these variables is mentioned in studies such as Kumar (2013); Fungáèová \& Weill (2016); Tuesta, Sorensen, Haring, \& Camara, (2015); Kedir (2003). Age and education level is a significant role player in financial exclusion, where young and educated people are less likely to be excluded than older and less knowledgeable members. (Johnson \& Nino-Zarazua, 2007; Sahoo, Pradhan, \& Sahu (2017).

Inequality of income arises among the group members on various issues such as age, gender, income, and economic status (Aslan, Delchet, \& Monique, 2017). The actual use of financial products like savings, term loans may be more helpful for those individuals having a regular income to save their money that can be used to pay any term loans to meet credit requirements (Kumar, 2013).

Having more number of earning members increases the household income and reduces the dependence of household on a single earning member and increases his/her chances of using 
the banking and financial services for the benefit of the household (Roy, S., Singh, H R., \& Singh, R., 2017a). The number of household members accessing financial services according to their needs to brings dynamism in financial inclusion (Sinclair, 2013). The economic status of the respondents plays a significant role in bringing people closure to the use of banking and financial services (Wangwe, 2004; Harris, Loundes, \& Webster, 1999)

Akpandjar, Quartey, \& Abor (2013) have also suggested that location characteristics are an essential factor in obtaining financial services. The demand-side barriers to financial inclusion are affected by location and personal elements of the respondents such as gender, education, income, religion, and occupation (Yadav \& Sharma, 2016). Religion as a factor may be influencing financial inclusion as shown in one study by Demirgüc, Klapper, \& L, (2013) and Bhattacharya (2016).

The study is an attempt to discern the factors which are responsible for financial exclusion. The conceptual framework is the result of a thorough literature review done in the area to understand the components. These input variables from various kinds of literature finally converge to decide the construct of financial exclusion, which is the output variable.

\section{The Model}

As discussed in the previous section holding the conceptual framework, the factors that influence the use of financial services are demographic characteristics, educational qualification of the user, economic status of the user, occupation, financial awareness, availability of business correspondents, the suitability of products (Perraudin \& Sorensen, (1992); Chen \& Chivaku, (2008). These variables form the shape of an equation (1) fitting into the model for empirical investigation of use for financial services by households. The model can be written as:

$$
U F S_{i}=f\left(D F_{i}, E D U_{i}, E S_{i}, I N C_{i}, O C U_{i}, F A S_{i}, C F I_{i}, S P_{i}, B C_{i}\right)
$$

Where $U F S_{i}$ - use of financial services by $i$ th household, $D F_{i}$ - demographic variable of households $i$ th household, $E D U_{i}$ - educational qualification of $i$ th household, $E S_{i}$ - economic status of the $i$ th household, $I N C_{i}$ - Income, $O C U_{i}$ - Occupation of $i$ th household, $F A S_{i}$ - financial awareness of $i$ th household, and $C F I_{i}$ - connectivity to financial institutions, $S P_{i}$ - suitable product responded by $i$ th household and $B C_{i}$ - services rendered by business correspondents to an $i$ th household.

The study on the dynamics of using financial services is a decision taken by the adult population to invest their money in mitigating any kind of uncertainties that may arise from happening of some events in the future. This decision of using financial services is in the interest of the people to safeguard themselves from future risk, act as social security in their old age. The measurement of either use or not using financial services can take only two values, say 1 and 0 . The dependent variable will evolve as a binary or dichotomous variable.

$$
\begin{aligned}
U F S_{i}= & \alpha_{0}+\alpha_{1} \sum_{i=1}^{n} D F_{i}+\alpha_{2} E D U_{i}+\alpha_{3} E S_{i}+\alpha_{4} I N C_{i}+ \\
& \alpha_{5} O C U_{i}+\alpha_{6} F A S_{i}+\alpha_{7} R C_{i}+\alpha_{7} R C_{i}+\alpha_{7} R C_{i}+\alpha_{7} R C_{i}+e_{i}
\end{aligned}
$$

Tobit models are an extension of linear regression and probit model. It is used especially when the regressed dependent variable is continuous. This model is used because the dependent variable is constrained that means it is censored as it can take two values that are positive value when someone is using financial services or zero for otherwise not using it (Kinsey, 1981). That is the reason why the Tobit regression model is also called a censored regression model. Using the ordinary least square method will lead to biased estimation of the factor as the respondents not using financial services will be truncated away (Austin, Escobar, \& Kopec, 2000). The study by using equation (2) will try to identify the factors affecting the use of financial services by the people in the rural areas given their features and features of financial institutions. There 
will be two sets of respondents one $\eta_{1}$ using financial services and having information about factors using financial services and $\eta_{2}$ not using but having information on not using financial services. So, the Tobit model can be expressed as:

$$
Y_{1}=\beta_{1}+\beta_{2} X_{i}+u_{i} p
$$

if $\beta_{1}+\beta_{2} X_{i}+u_{i} p>0$

Where $Y_{1}$ is the dependent variable representing the use or disuse of financial services. This also acts as a demand, but just having a demand will not lead to the use of financial services if the factors are not taken care of. So in the above equation $Y_{1}, X_{i}$ is the explanatory variable affecting the use of financial services, $u_{i} s$ is the error term assumed to have a normal distribution with uniform variance.

The Tobit model uses Maximum Likelihood Estimation (MLE) for the estimation of both $\beta$ and $\sigma$ for the said censored normal regression model. The probability estimation is given below:

$$
\operatorname{Pr}\left[Y_{i}=\frac{0}{X_{i}}\right]=\operatorname{Pr}\left[X_{i} \beta+\varepsilon_{i}=\frac{0}{X_{i}}\right]=\operatorname{Pr}\left[\varepsilon i=-X_{i} \beta / X_{i}\right]=\operatorname{Pr}\left[\frac{\varepsilon_{i}}{\sigma} \leq \frac{X_{i} \beta}{\sigma} / X_{i}\right]
$$

Description of various factors applied in the model to assess the demand for using various financial services are given below.

Use of Financial Services $\left(U F S_{i}\right)$ : Demand for various banking and financial service is a censored variable and is used as a dependent variable in the study. The demand-side factors of financial services reflect the demand for financial services that arise from the use of savings products, credit facilities, insurance policies, remittances, a combination of any one or all four products comprises of services offered by financial institutions. Usage will be marked as 1 and non-usage as 0 .

Demographic Factors $\left(D V_{i}\right)$ : These are a set of characteristics of the end-users that consist of their age, gender, marital status, and ethnic group. The gender of the respondents is a dummy variable defined as 0 if the respondent is a female and 1 if the respondent is male. The ethnicity of the respondents is also defined as a dummy, where tribal means 1 , and non-tribal means 0 .

Educational Qualifications $\left(E D U_{i}\right)$ : Education of a person has the ability to understand the financial requirement better. The financial inclusion set to increase with the increase in basic education as against an illiterate person is more dependent on the informal source of finance. The study will consider the educational qualification as a characteristic of determinants of using financial products and services. A person not having a formal education will have a value equal to 0 . If completed, vocational or skill development training will take the value equal to 1 . If completed schooling will take the value of 2 and if having an undergraduate course will have a value of 3 . At last, if the user has undergone any postgraduate course will take the value equal to 4 .

Economic Status $\left(E S_{i}\right)$ : Economic status is measured by the poverty line. The poverty line considered in this study is as per the Tendulkar committee report that defines it based on daily per capita expenditure for rural and urban areas separately. This variable consists of two things either below the poverty line where the daily per capita expenditure is below Rs. 27 and Rs. 33 for rural and urban area respectively. If the respondent falls below the poverty line then the dummy will take the value of 0 . In case the respondent is above the poverty line, it will take the value of 1 .

Income $\left(I N C_{i}\right)$ : Income of the individual is categorized as salaried who receives regular income. This category is valued at 1 , and that non-salaried personnel with irregular income are valued at 0 .

Occupation $\left(O C U_{i}\right)$ : Occupation means monetary engagement in any work. This variable consists of occupation in Government/Semi-Government/Quasi-Judicial bodies where regular income is received. This variable takes the value of 1 if the main occupation of the respondent 
is in Government or its related organizations. If otherwise, the main occupation is not in a government organization but maybe in agricultural and allied activities, then it will take the value of 0 .

Financial Awareness Score $\left(F A S_{i}\right)$ : This variable is calculated from the responses given by the respondents that consist of questions to test the awareness about various financial and banking products that are offered by the financial institutions. The products taken to measure financial awareness are related to credit, savings, investments, insurances. An overall financial awareness score is calculated based on the awareness level of the above-mentioned product and services using a simple scoring method.

Connectivity to Financial Institutions $\left(C F I_{i}\right)$ : Rural connectivity has proper roads and infrastructure to access the financial institutions. This variable takes the score of 0 if proper roads and physical infrastructure are not present and 1 if it's there.

Suitability of Product $\left(S P_{i}\right)$ : Use of a financial product depends on its relevance. The literature suggests that a financial product is demanded and used by the customer if its features satisfy the needs of the user. Suitability depends on the perceived inherent characteristics of the product that a user understands to give certain financial benefits in times of distress. As the study focuses on rural users where the constraint is maximum and restricts the use to a great extent. The question about the suitability is asked if the user finds the product suitable according to his financial needs takes the value 1 , and the product is not suitable if it does not bring the perceived benefits takes the value 0 .

Business/Banking Correspondents $\left(B C_{i}\right)$ : Business correspondents are the banking channel partners who take the banking product and services to interior places where brick and mortar branch or ATM kiosks are not available. They act as an agent for the banks or financial institutions to spread the use of various banking and financial services and reach the maximum number of people. Their presence is considered as a factor augmenting in the use of financial services. The questions take the value of 1 if such agents are present in those areas if otherwise then 0 .

\begin{tabular}{|c|c|}
\hline \multicolumn{2}{|c|}{ Table 1: Variable Descriptions } \\
\hline Variables $(i)$ & Explanation \\
\hline \multirow{6}{*}{ Use of Financial Services $\left(U F S_{i}\right)$} & $=0$, if not using any financial services \\
\hline & $=1$, If using the only savings bank account \\
\hline & $=2$, If using a credit facility from the bank \\
\hline & $=3$, If having an insurance policy \\
\hline & $=4$, If using any two combination \\
\hline & $=5$, If using any three combination \\
\hline \multirow{15}{*}{ Demographic factors $\left(D V_{i}\right)$} & Gender \\
\hline & $=1$, if Female \\
\hline & $=0$, if Male \\
\hline & Marital Status \\
\hline & $=0$, if Married \\
\hline & $=1$, if Not married \\
\hline & $=2$, if Separated/Divorced \\
\hline & Age \\
\hline & $=1,18-30$ years \\
\hline & $=2,31-40$ years \\
\hline & $=3,41-50$ years \\
\hline & $=4$, above 50 years \\
\hline & Ethnicity \\
\hline & $=1$, Tribal Community \\
\hline & $=0$, Non-Tribal Community \\
\hline
\end{tabular}




\begin{tabular}{|c|c|}
\hline \multirow{6}{*}{ Educational Qualifications $\left(E D U_{i}\right)$ : } & Educational Qualification \\
\hline & $=0$, No Formal Education \\
\hline & $=1$, Completed Vocational Training \\
\hline & $=2$, Completed School Education \\
\hline & $=3$, Completed College Education \\
\hline & $=4$, Completed University Education \\
\hline \multirow{3}{*}{ Occupation $\left(O C U_{i}\right)$ : } & Occupation \\
\hline & $=1$, Government \\
\hline & $=0$, Non-Government \\
\hline \multirow{3}{*}{ Income $\left(I N C_{i}\right)$ : } & Income \\
\hline & $=1$, Regular Income \\
\hline & $=0$, Irregular Income \\
\hline \multirow{3}{*}{ Economic Status $\left(E S_{i}\right)$ : } & Economic Status \\
\hline & $=1$, Above poverty line \\
\hline & $=0$, Below poverty line \\
\hline \multirow{6}{*}{ Financial Awareness Score $\left(F A S_{i}\right)$} & Index of Financial Awareness \\
\hline & $=5$, Very Highly Aware \\
\hline & $=4$, High Awareness \\
\hline & $=3$, Medium Awareness \\
\hline & $=2$, Low Level of Awareness \\
\hline & $=1$, Very Low Level of Awareness \\
\hline \multirow[t]{2}{*}{ Connectivity to Financial Institutions $\left(C F I_{i}\right)$ : } & $=1$, Well Connected by Roads \\
\hline & $=0$, If Otherwise \\
\hline \multirow[t]{2}{*}{ Suitability of Products $(S P i)$ : } & $=1$, Product suitable per affordability and needs \\
\hline & $=0$, If Otherwise \\
\hline \multirow[t]{2}{*}{ Business Correspondence $\left(B C_{i}\right)$} & $=1$, Presence of business Correspondents \\
\hline & $=0$, If Otherwise \\
\hline
\end{tabular}

\section{Sampling design}

The study is confined to the jurisdiction of North East India. Two members' form each household consists of the sampling unit. During the course of primary data collection, a total of 1,000 households from three states of North Eastern India were surveyed constituting a total sample of 2,000 respondents selected using a simple random sampling. The three states are selected based on their financial inclusion index ranked according to their inclusiveness in the formal financial system. The states are Tripura, Assam, and Mizoram. The responses of the people were collected using a structured questionnaire distributed to the people living in both rural and urban areas. Out of the total questionnaire collected, 52 questionnaires were found to be defective, and the remaining 1,948 questionnaires were taken for the study.

\section{Analysis and Findings}

The Tobit regression model was run to analyze the collected data. The dependent variable representing the study is the use of anyone or all of the financial services versus not using any of the financial services. Tobit regression will regress the censored dependent variable on the nine independent variables to measure the outcome. The normality of data is assumed to have occurred when the error term is normally distributed. This can be tested using the Bera-Jarque test, to check for the presence of skewness and kurtosis using the formulae:

$$
W=T\left[\frac{b_{1}^{2}}{6}+\frac{\left(b_{2}-3\right)^{2}}{24}\right]
$$

where, $b_{1}$ - coefficient of skewness, $b_{2}$ - coefficient of excess kurtosis, $T$ - number of observations. 
At $\alpha=0.05$ significance level, the Bera-Jarque statistics show the error term to be normally distributed. Simultaneously there is a necessity to test the fitness of the model in the study frame to test whether the independent variable combined significantly contributes to the outcome of the dependent variable. One of doing this is to compare the predicted values based on the Tobit model with the observed values in the data set. This can be done using qlim (qualitative and limited dependent variable model) to generate the predicted values and compare the same with the observed values using correlation. The output of the correlation between the predicted and observed value is 0.74301 . When we square the value of correlation, the result which comes is 0.55207 that indicates the predicted values contribute $55 \%$ of their variance with the observed values of the dependent variable.

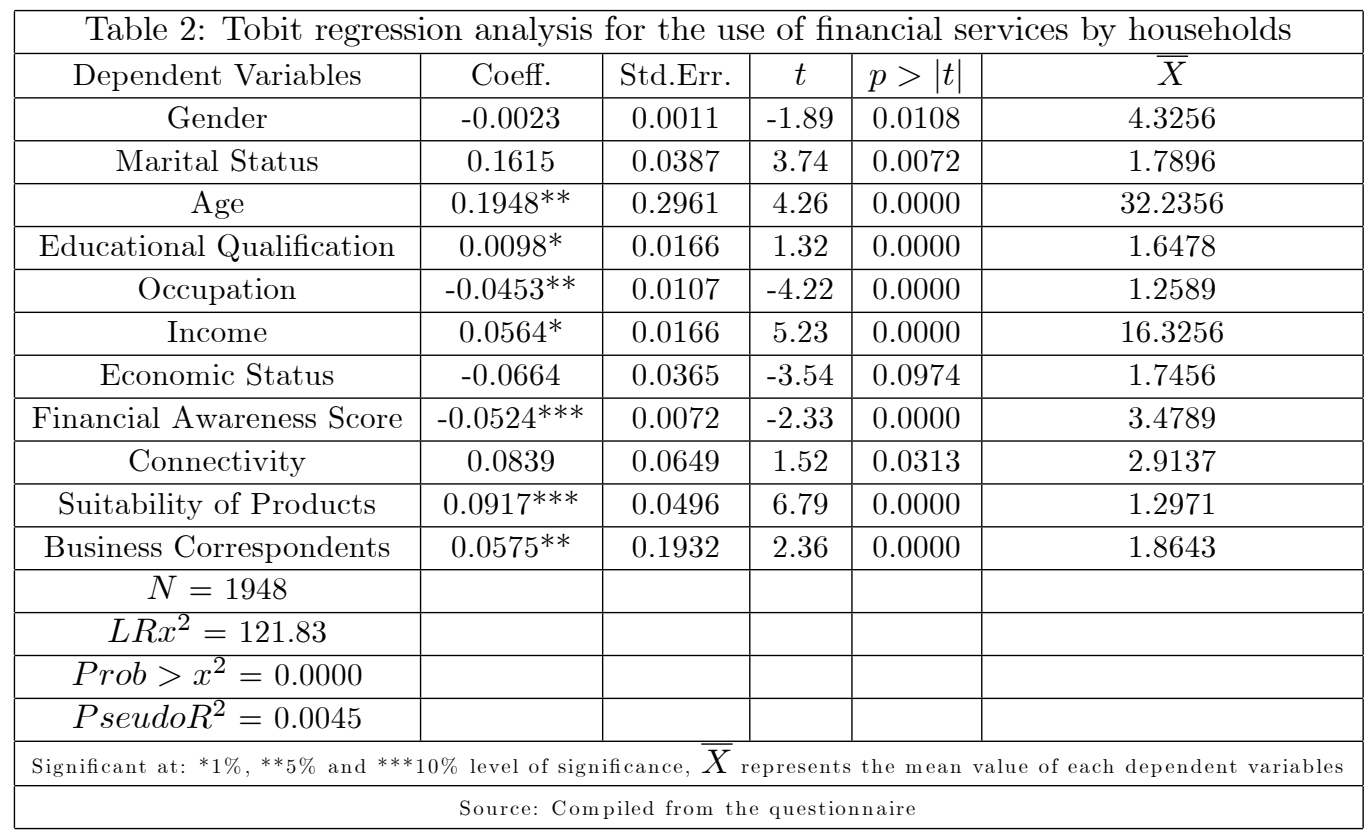

The primary concern of all the policymakers is to take formal financial and banking services to the poor masses and make them use these products and services for their betterment. This is particularly important for the North Eastern States of India which is low in banking penetration. An intensive study of the literature has suggested narrowing down some critical factors affecting the use of financial services which are identified and categorized into eleven factors that may affect the use and access to various basic banking and financial services among the people in the North-Eastern states. The factors are gender, marital status, age, educational qualification, occupation, income, economic status, financial awareness, connectivity to financial institutions, the suitability of the product, and the presence of business correspondence. Among these factors, seven factors seem to be statistically significant having a direct or indirect impact on one's decision to use a financial service. This finding is supported by Kumar (2013); Kempson \& Whyley (1999); Leyshon \& Thrift (1995); Allen, Demirgüç-Kunt, Klapper, Soledad, \& Peria, (2012); Clamara, Peña, \& Tuesta (2014).

There is a vast population in India in the informal sector that does not avail of the fundamental requirement through formal banking and financial services. The factors identified above will help the banks and regulators to understand the reason for people's affinity towards informal financial services instead of formal ones (Buera \& Yongseok, 2010).

It is also found that the suitability of the product and financial awareness/education has a significant impact on the use of financial products and services. Thus, it can be inferred that if banking rules are simplified for the ordinary and poor people, it will help them to avail the banking facilities to the best of their need and benefits. The success of Prime Minister Jan Dhan Scheme in India is the testimony of this fact. Similarly, spreading awareness about various 
banking and financial services is expected to increase the use of financial services (Feldstein and Horioka, 1980).

Gender and age are seen as a significant factor and are consistent with other studies where similar findings were derived (Devlin, 2005; Argent \& Rolley, 2000; Sangwan, 2008; Rangappa, Bai, \& Sandesh, 2009). Young and educated people are more likely to use financial services than old and illiterate people (Johnson \& Nino-Zarazua, 2007). The study revealed that a female member increases the probability of use of financial services than their male counterpart. The reason for the high share of a female member in the use of financial services is because the business culture in the northeastern region is mainly dominated by female members in most of the states. This finding is contradictory to many studies where male members lead in decision making in the family and thus also have used financial services more than females.

This study gradually develops a fundamental approach to the association between financial inclusion and demographic characteristics of the people in North East India. The design of financial products and services such as investments, insurance, remittances, overdraft, direct benefit transfer, etc. are to be designed according to the demographic requirement of these users in the region, and through financial counseling and creating awareness, the people will be required to understand the importance of formal financial services in their economic growth. The banking sector, as well as the government, should rework their priority area to remove the barriers as discussed above and make way for the people to use formal banking products and services.

Education is an essential factor in the path towards financial inclusion. It enables a person to make informed decisions weighing the pros and cons of service (Johnson \& Nino-Zarazua, 2007). The present study also reiterates the importance of education in promoting maximum usage of financial services in an economy. The education level has a significant and positive relationship with the use of financial services. This relationship between education and financial inclusion through the use of financial services has been supported by several studies earlier (Ghosh, 2012). There is an increase in the use of financial services with the rise in educational levels. Being educated, they understand the benefit of formal financial services like taking a loan from banks instead of informal sources which charges an excessive rate of interest.

The study of available literature suggests that personal income is a crucial factor in determining the use of financial services. The present study has also found that personal income has a statistically significant and positive relationship with the use of financial services. People in the low-income category, especially in the hilly areas, mostly demand less of the financial services. This becomes a concern while selling the banking products as there is an increase in income inequality due to skewed uses of financial services. When people have access to unbiased and constraint-less finance then it can lower the inequalities in income (Honohan, 2008). In other words, the use of finance products increases, with the increase in the income of the people resulting in reducing the income inequalities and poverty level at the macro-economic level (Chattopadhyay, 2011).

This is encouraging to see that the study revealed a statistically significant association between economic well-being and the use of formal financial services to sustain the minimum charges required to maintain the obligations arising out of using different services. Poor people are more intended to be low in use as they don't have sufficient income to access the financial services offered by banks and other financial institutions. The use of financial services and products are low among the BPL category members.

Financial awareness score with a $p$-value less than 0.05 resulted from Tobit regression states a statistically significant relationship between financial awareness of the respondents and their use of various financial services. Financial awareness and financial inclusion are positively related that provide people with short term and long term financial gains to help them grow economically by mitigating their future losses (Stiglitz \& Weiss, 1981). The increase in financial awareness increases the probability of the use of financial services. Thus policy in improving the awareness level of the people should act as a motivator, supplemented to enhance their 
level of use (Loomes \& Sugden, 1982). The demand for a financial product will depend on its utility and price. The study found that the suitability of the product has a significant direct relationship with its usage. With the increase in product utility, demand and usage are going to show an upward trend. The policymakers will need to rethink the traditional approach of banking such as more documentation and complicated products \& services with simple, easy and convenient ones to manage their irregular flow of income.

The demand side reason for suitability of financial products is a vital factor for the use of financial services as conditions attached to a product and its price makes a product unattractive among the poor and generates less demand of it leading to exclusion from the mainstream financial services (Kempson \& Whyley, 1999), (Leyshon \& Thrift, 1995). These barriers are the outcome of the structural system that exists in the financial sector (Lunt, 1992). When the demand for financial services arises, it does not lead to use always because access to it is also vital in the system. The business correspondents employed by banks take forward the banking and financial services where the presence of brick and mortar branch is not available because of steep terrain. The study shows the importance of business correspondence which is statistically significant.

\section{Conclusion}

Data from various areas of North Eastern states have contributed immensely to the study in finding out and understanding the different impediments that affect the use and access of essential financial services offered by banks in the region. North-Eastern region is an area which has been neglected for many years - analyzing the RBI's (Reserve Bank of India) basic statistical return data where there has been an increase in the number of commercial bank branches, but despite an increase in the number of bank branches, the penetration of financial services is abysmally low in the region. This situation compels us to understand the system from the demand side, which is the reason for the low penetration of financial services because of its little acceptance among the poor masses. The region has seen some presence of MicroFinance Institutions offering some credit-based financial services, but this does not ensure the welfare of the people because of the vested interest of the microfinance institutions charging a high rate of interest. Some of the states like Assam and Tripura have a considerable presence of MFIs, but other states in the region lack it.

Creating access to easy credit is important which the RBI and Govt. are trying to do, but other banking services like savings, insurance, investment, pension, and remittances are also essential for the overall and sustainable growth of the people in the region. For this overall growth, there is a need for developing a public-private partnership. RBI and the DONER (Ministry of Development of North-East Region) organizations should increase its coordination with the NBFCs, MFIs, NEC (North Eastern Council), NERAMAC (North Eastern Regional Agriculture and Marketing Corporation Ltd.), NEHHDC (North East Handicrafts and Handloom Development Corporation) to reach the masses.

The study is not only interested in understanding the impediments to use and access to financial services but also tries to shed light on the welfare impact of removing these barriers. Further, the study would like to broaden the scope of its research in determining how the removal of these impediments would affect the welfare of the households in the long run.

The RBI and the Government, in collaboration with banks, should consider this information while simplifying the process of doing banking and disbursing credit to marginalized people. Better financial awareness, removing physical infrastructure bottlenecks, improving economic conditions, streamlines the products, and services is an essential condition to take a step forward.

\section{REFERENCES}

[1] Abiad, V.G., Cuevas, C.E. and Graham, D.H., (1988). Borrower transaction costs and credit rationing in rural financial markets: the Philippine case, ACPC Working Paper Series No. 88-09 by the Agricultural Credit Policy Council. 
[2] Allen, F., Demirgüç-Kunt, A., Klapper, L., Soledad, M., \& Peria, M. (2012) The Foundations of FI. Understanding Ownership and Use of Formal Accounts. Policy Research Working Paper, The World Bank. Development Research Group, Finance, and Private Sector Development Team.

[3] Aslan, G., Delchet, G., \& Monique, N. (2012) Inequality in Financial Inclusion, Gender Gaps, and Income Inequality. IMF Working Papers, pp.2-32.

[4] Austin, P., Escobar, M., \& Kopec, J. (2000). The use of the Tobit model for analyzing measures of health status. Quality of Life Research , 9 (8), 903.

[5] Bartholomew, D. and Child, D. (1980). Factor Analysis for Categorical Data. Journal of the Royal Statistical Society. Series B (Methodological), Vol-42, Issue-3, pp. 293-321.

[6] Beck, T., Demirgüç-Kunt, A., \& Martinez Peria, M. (2008) Banking Services for Everyone? Barriers to Bank Access and Use around the World. World Bank Economic Review Vol-22, Issue (3), pp 397-430.

[7] Bhattacharyay. (2016). Determinants of Financial Inclusion of Urban Poor in India: An Empirical Analysis. CESIFO Working Paper Series No. 6096.

[8] Brynjolfsson, E., \& Hitt, L., (2000). Beyond Computation: Information, Technology, Organizational Transformation, and Business Performance. Journal of Economic Perspectives, Vol-14, Issue-4, pp. 23-48.

[9] Buera Fransisco.J, \& S, Yongseok. (2010). Financial Frictions and the Persistence of History: A Quantitative Exploration. NBER Working Paper No. 16400, pp. 1-42.

[10] Camara, N., Pena, X., \& Tuesta, D. (2014). Factors that Matter for Financial Inclusion: Evidence from Peru. The International Journal of Finance, pp. 22-36.

[11] Campbell, J. Y. (2006). Household Finance. Journal of Finance, Vol-12, Issue-03, pp. 1553-1604.

[12] Chattopadhyay, S.K. (2011), Financial Inclusion in India: a case study of West Bengal, Working Paper Series No. 8/2011, Department of Economic and Policy Research, Reserve bank of India, Kolkata.

[13] Chen, C.K. \& Chivaku, M. (2008), What drives household borrowings and credit constraints? Evidence from Bosnia and Herzegovania, IMF working paper Vol 8, Issue (202).

[14] Child, D. (2006). The essentials of factor analysis. New York, NY: Continuum International Publishing Group.

[15] Clarke, George, R., L., C. X., \& Zou, H.-F., (2006). Finance and income inequality: What do the data tell us? Southern Economic Journal, pp. 578-596.

[16] Collins, \& Daryl. (2009). Portfolios of the Poor. New Jersey: Princeton University Press.

[17] Das, P., (2010). The Up-Scaling of Technology to Build Inclusive Financial Systems in India. Journal of Education Administration and Policy Studies, Vol-2, Issue-5, pp.67-70.

[18] Demirgüc, K., Klapper, A., \& L, R. (2013). Islamic Finance and Financial Inclusion: Measuring the use of the demand for Formal Financial Services among Muslim Adults. Policy Research Working Paper No. 6642, The World Bank, Washington DC.

[19] Demirgüc-Kunt, A., \& Klapper, L., (2013). Measuring Financial Inclusion: Explaining Variation in Use of Financial Services Across and Within Countries. Brookings Papers on Economic Activity, Vol-44, Issue-1, pp. 279-340.

[20] De Matteis, L. (2015). Financial Inclusion: Policies and Instruments for Migrants in Italy. Savings and Development, 39-69. Retrieved from https://www.jstor.org/stable/savideve.2015.39.

[21] Fernandes, D., Lynch Jr., J. G., \& Netemeyer, R. G., (2014). Financial Literacy, Financial Education, and Downstream Financial Behaviors. Management Science, pp. 1861-1883.

[22] Ford, J., \& Rowlingson, K., (1966). Low-income Households and credit: Exclusion, Preference, and inclusion. Environment and Planning, Vol-28, Issue-8, pp. 1345-60.

[23] Fungáčová, Z., Weill, L. (2013). Does Competition Influence Bank Failures? Evidence from Russia. Economics of Transition 21, 2, pp. 301-322.

[24] Gangopadhyay, S., (2009). How Can Technology Facilitate Financial Inclusion in India? A Discussion Paper. Review of Market Integration, Vol-1, Issue-2, pp. 223-256.

[25] George, D., \& Mallery, P., (2003). SPSS for Windows step by step: A simple guide and reference 11.0 update (4th ed.). Boston: Allyn \& Bacon.

[26] Ghosh, S. (2012), Determinants of banking outreach: an empirical assessment of Indian states, The Journal of Developing Areas, Vol. 46 No. 2, pp. 269-295.

[27] Gupta, S. K., (2011). Financial Inclusion - IT as enabler. Reserve Bank of India Occasional Papers, Vol-32, Issue-2, pp. 129-148.

[28] Harman, H., 1976. Modern factor analysis. Chicago, IL: University of Chicago Press.

[29] Harris, M., Loundes, J., \& Webster, E., (1999). Determinants of household saving in Australia. Melbourne Institute Working Paper, Vol-22, Issue-99, pp. 1-22.

[30] Hilgert, M., Hogarth, J., \& Beverley, S., (2003). Household financial management: The connection between knowledge and behavior. Technical report No-309-322. Federal Reserve Bulletin, pp. 56-69.

[31] Hishigsuren, G., (2006). Information and Communication Technology and Microfinance: Options for Mongolia. ADB Institute Discussion Paper No. 42, pp. 1-30.

[32] Honohan, P. (2008), Cross-country variation in household access to financial services, Journal of Banking and Finance, Vol. 32 No. 11, pp. 2493-2500. 
[33] Johnson, S., \& Nino-Zarazua, M. (2007), www.fsdu.or.ug. Retrieved November 2, 2016, from www.fsdu.or.ug/pdfs/financial $\% 20$ Exclusion $\% 20 \mathrm{~m} \%$ Uganda $\% 20$.

[34] Kant K (2014), "Households Put Two-Thirds of Their Savings into Houses, Gold," Business Standard published on 31.05.2014 and retrieved on 1.03.2017.

[35] Karlan, D., \& Morduch, J., (2009). Access to Finance Chapter 2. In Handbook of Development Economics. North Holland.

[36] Kedir, A., (2003). Determinants of Access to Credit and Loan Amount: Household-level Evidence from Urban Ethiopia. International Conference on African Development Archives.

[37] Kempson, E., \& Whyley C., (1998). Access to Current Account. London: British Bankers' Association.

[38] Kempson, E., \& Whyley, C., (1999). Kept Out? or Opted Out? Understanding and combating financial exclusion. Bristol, Great Britain: The Policy Press.

[39] Kinsey, J. (1981). Determinants of credit card accounts: an application of Tobit analysis. The Journal of Consumer Research, 8 (2), 174.

[40] Kumar, C., \& Mishra, S., (2011). Banking Outreach and Household level Access: Analyzing Financial Inclusion in India. 13th Annual Conference on Money and Finance in the Indian Economy, pp. 1-33.

[41] Kumar, N. (2013). Financial inclusion and its determinants: evidence from India. Journal of Financial Economic Policy, Vol-5, Issue-1, pp. 4-19.

[42] Leyshon, A., \& Thrift, N., (1995). 'Geographies of financial exclusion: financial abandonment in Britain and the United States. Transactions of the Institute of British Geographers, New Series, Vol-20, Issue-3, pp. 312-341.

[43] Loomes, G., \& Sugden, R., (1982). Regret Theory: An Alternative Theory of Rational Choice Under Uncertainty. The Economic Journal, 805-824.

[44] Lusardi, A., \& Mitchell, O., (2006). Financial literacy and planning: Implications for retirement wellbeing. Wharton School, University of Pennsylvania Pension Research Council Working Paper No-1, pp. 2-31.

[45] Lusardi, A., \& Olivia, M. S., (2011). Financial Literacy around the World: An Overview. Journal of Pension Economics and Finance, pp. 497-508.

[46] Moore, D., (2003). Survey of Financial Literacy in Washington State: Knowledge Behavior, Attitudes, and Experiences. Washington State University: Social and Economic Sciences Research Center.

[47] Nair, T. S., \& Tankha, A., (2015). Inclusive Finance India Report 2014. New Delhi: Oxford University Press.

[48] Nunnally, J. (1978). Psychometric Theory. New York: McGraw Hill.

[49] Nwuke, K. (1997). Transactions Cost and Savings Mobilization: Evidence from Six Sub Saharan African Countries. UNECA

[50] Perry, V. G., \& Morris, M. D., (2005). "Who Is in Control? The Role of Self Perception, Knowledge, and Income in Explaining Consumer Financial Behavior. Journal of Consumer Affair, pp. 299-313.

[51] Perraudin, R.M \& Sorensen, B.E (1992), The credit-constrained consumer: an empirical study of demand and supply in the loan market", Journal of Business and Economic Statistics, Vol.10, Issue (2), pp172-192.

[52] Raheem, A. A. (2012). Women Empowerment through Self Help Groups (SHGs). New Delhi: New Century Publications.

[53] Rogers, E., (2003). Diffusion of Innovations, New York, Free Press.

[54] Roy, S., Singh, H R., \& Singh, R. (2017). Factors Affecting the Financial Inclusion of SHG Members: An Empirical Study in Tripura. IUP Journal of Bank Management, 16 (3): pp. 59-83.

[55] Roy, S., Singh, R. H., \& Singh, R. (2017). Demand Factors that Influence Financial Inclusion of SHG Members in Tripura: An Analysis of the Barriers Based on Empirical Study. International Journal of Money, Banking and Finance, Vol-6, Issue-1, pp. 40-50.

[56] Sahoo, Pradhan, \& Sahu. (2017). Determinants of Financial Inclusion in Tribal Districts of Odisha: An Empirical Investigation, Vol-47, Issue-1, pp. 45-64.

[57] Sinclair, S., 2013. Financial inclusion and social financialization: Britain in a European context. International Journal of Sociology and Social Policy, Vol-33, Issue- (11/12), pp. 658-676.

[58] Sinha, S., Pandey, K. R., \& Madan, N. (2018). Fintech and the demand side challenge in financial inclusion. Enterprise Development \& Microfinance, 29 (I), 26-37.

[59] Stiglitz, J., \& Weiss, A. (1981). Credit rationing in markets with imperfect information. American Economic Review, 393-410.

[60] Tabachnik, B., \& Fidell, L., (2007). Using multivariate. Boston: MA: Allyn \& Bacon.

[61] Tuesta, D., Sorensen, G., Haring, A., \& Camara, N., 2015. Financial inclusion and its determinants: the case of Argentina. BBVA Research Working Paper 15/03, pp. 2-28.

[62] Wangwe, S., (2004). Innovation in Rural Finance in Tanzania. Paper presented at the Third Annual Conference on Microfinance, AICC, Tanzania.

[63] Yadav, P., \& Sharma, A. K. (2016). Financial inclusion in India: an application of TOPSIS. Humanomics, Vol-32, Issue-3, pp. 328-351.

[64] Zins, A. \& Weill, L., (2016). The determinants of financial inclusion in Africa. Review of Development Finance, Vol-6, Issue-1, pp. 46-57. 